\title{
The Research on Factors Which Affect Anti-dumping Investigation: Based on Probit Model
}

\author{
Rou $\mathrm{Li}^{1}$ \\ ${ }^{1}$ School of International Trade and Economics, Central University of Finance and Economics, P. R. China \\ Correspondence: Rou Li, School of International Trade and Economics, Central University of Finance and \\ Economics, Beijing 100081, P. R. China. E-mail: 2007lirou@163.com \\ Received: January 14, 2018 \\ Accepted: February 16, 2018 \\ Online Published: February 25, 2018 \\ doi:10.5539/ijbm.v13n3p252 \\ URL: https://doi.org/10.5539/ijbm.v13n3p252
}

\begin{abstract}
Using country-industry data, this study investigates factors which affect anti-dumping investigation via Probit model. We find that with the increase of trade, GDP per capita, population, exchange rate, accession to WTO and the occurrence of financial crisis, China more likely suffer from anti-dumping investigation, while with the increase of distance, China less likely suffer from anti-dumping investigation. Further, after divided the export into extensive margin and intensive margin, we find that the negative effect of trade on anti-dumping investigation mainly comes from the increase of intensive margin. The increases of extensive margin may reduce the chances of suffering from anti-dumping investigation.
\end{abstract}

Keywords: Anti-dumping, probit model, influence factors

\section{Introduction}

With China's accession to the WTO, China experiences a great increase in export, surpassing the United States as the world's second largest exporter in 2007, and overtaking Germany to be the world's largest exporter in 2009. However, with the development of export, China also suffered a lot from anti-dumping investigation with total 1414 annual average 51.4 during 1995-2013. Besides, since Donald Trump was selected as the new president of the United States in 2016, trade protection booms again in the United States with exiting from the Trans Pacific Partnership Agreement (TPP), renegotiation the North American Free Trade Agreement (NAFTA), revision the U.S. - Korea Free Trade Agreement, and tax reform to attract inflows of capital. So currently it is theoretical and practical significance to study the factors which affect the investigation of anti-dumping.

\section{Literature Review}

There are many factors which affect anti-dumping investigations. Generally, these factors can be divided into economic and politic factors. From the point of economic factors, Knetter and Prusa (2003) point out that with the GDP increased by $1 \%$, the application of anti-dumping will decline about $23 \%$. Xie (2006) infers that the fluctuation of the US's domestic industrial output will significantly increase the frequency of the US's anti-dumping investigations. Irwin (2005) confirms that unemployment rate in the United States positively correlate to the number of anti-dumping investigations. Zhang and $\mathrm{Wu}$ (2005) analyze the effect of production equipment utilization ratio and GDP growth rate on the anti-dumping application by importer. As for the effect of trade on anti-dumping investigation, Baldwin (1985) and Pursa (1998) point out that since the increase of import products will destroy domestic manufacturer, the application of anti-dumping investigation may closely corelate with import. Mah (2000) infers that trade balance have a unidirectional effect on the rate of anti-dumping confirm damage proportion. Prusa (2005) points out that the reason for anti-dumping investigation is the growth of trade. Aggarwal (2004) confirms that the number of anti-dumping implication significantly correlate to the expansion of countries' trade deficit and the increase of import. Shen (2007) infers that the decrease in the proportion of China's export to the United States will reduce the number of US anti-dumping investigations. Xie (2006) infers that the expansion of trade deficit between the US and China will statistically significant increase the frequency of anti-dumping investigations by the United States.

From the point of politic factors, exchange rate has a significant effect on anti-dumping investigation. Feinberg (1989) infers that the depreciation of the dollar will significantly increase the application of anti-dumping towards Brazil, Japan, South Korea and Mexico by the U.S.. Knetter and prusa (2003) show that if currency 
increase $1 \%$, the anti-dumping application by domestic enterprises will increase about $33 \%$. As for the effect of WTO accession, Aggarwal (2004) infers that anti-dumping increase after the establishment of WTO. Feinberg and Reynolds (2007) infer that countries tend to protect domestic market with anti-dumping after making a commitment of dramatic reductions in tariff in the GATT Uruguay round of negotiations.

To sum up, we find that export is an important factor for anti-dumping investigation, but when we divided the export in to extensive margin (the category of products) and intensive margin (trade value of each product), then which margins of export matters are unclear. Besides, after 2008 financial crisis, a new round of trade protection was launched to safeguard a country's industry and trade. Therefore, this study also treat crisis as an important factor in anti-dumping investigation. In addition, since the anti-dumping takes place in a certain industry, we do the research based on SITC two-digits industry. The possible contributions of our study including, (1) analyze the effects from the points of economic and politic at the same time;(2) since export is an important factor in anti-dumping investigation, we will divide the export into extensive margin and intensive margin to make a deep research.

\section{Methodology}

\subsection{Econometric Model}

Since Probit model can better estimate two value selection problem, so this study uses Probit model to verify factors which affect anti-dumping investigation. The specification for our probit estimation is:

$$
\begin{aligned}
& \text { Probit (ADP jdo })=\beta_{0}+\beta_{1} \text { trade }{ }_{\text {jod }}+\beta_{2} \text { gdp }_{\mathrm{d}}+\beta_{3} \mathrm{popu}_{\mathrm{d}}+\beta_{4} \mathrm{dis}_{\text {od }}+\beta_{5} \text { wto }{ }_{\text {to }}+\beta_{6} \text { pta od } \\
& +\beta_{7} \mathrm{ta}_{\text {od }}+\beta_{8} \text { exch }_{i j}+\beta_{9} \text { crisis }+\chi_{\mathrm{d}}+\mu_{j}+u_{i j}
\end{aligned}
$$

among which, there are three variables to measure anti-dumping $\mathrm{ADP}_{\text {jod }}$, the first one is $\mathrm{ADP} 1_{\mathrm{jdo}}$, which represents anti-dumping cases launched by country $d$ towards country o industry $j$, the sigh is 1 for yes otherwise 0 . The seconds is $\mathrm{ADP} 2_{\mathrm{jdo}}$, which represents the number of anti-dumping cases launched by the country $\mathrm{d}$ toward country o industry $\mathrm{j}$; the third one is $\mathrm{ADP} 3_{\text {jdo }}$, which divides $\mathrm{ADP} 2_{\text {jdo }}$ into 6 levels with zero case of anti-dumping recorded as 0,1 case of anti-dumping recorded as 1,2 cases of anti-dumping recorded as 2, 3 cases of anti-dumping recorded as 3, 4 cases of anti-dumping recorded as 4, 5 to 9 cases of anti-dumping recorded as 5, 11 to 25 cases of anti-dumping cases recorded as 6 .

Intrade $_{\text {odj,t }}$ represents country o export to country $\mathrm{d}$ in industry $\mathrm{j}$ year $\mathrm{t} . \mathrm{EM}_{\mathrm{odj}, \mathrm{t}}$ represents the extensive margin of country o to country $\mathrm{d}$ in industry $\mathrm{j}$ year $\mathrm{t}$, and $\mathrm{IM}_{\mathrm{odj}, \mathrm{t}}$ represents the intensive margin of country o to country $\mathrm{d}$ in industry $\mathrm{j}$ year t. Based on the method of Hummels and Klenow (2005) and Dutt (2013), we calculate the extensive margin and intensive margin. Specifically, the extensive margin is $\mathrm{No}_{\mathrm{dj}}$, which represents the types of products country o export to country $d$ in industry j. Intensive margin is $\bar{X}_{\text {odj }}=X_{\text {odj }} / \mathrm{N}_{\text {odj }}$, where $X_{\text {odj }}$ is the total export from country o to country $\mathrm{d}$ in industry $\mathrm{j}$, so the intensive margin represents the average export of each product in industry $\mathrm{j}$.

The rest of variables including country d's GDP per capital, country d's population, capital distance between country o and country d, China's WTO accession, signing the Free Trade Agreement, country d's average tariff, country o's currency exchange rate against the dollar, 2008 financial crisis.

In addition, this study also estimates in Ordered Probit mode. When the option in dependent variable is s, and $Y_{i}=j(j=0,1,2, \cdots, s-1$, and $0<1<2<\cdots \cdots<s-1)$ is decided by the hypothetical variable $Y^{*} i\left(\alpha_{j}<Y_{i} \leq \alpha_{j+1}\right.$, $\alpha$ determined by the threshold $)$, the probability of $Y_{i}=j$ can be write as $P\left(Y_{i}=j \mid X_{i}\right)=F\left(\beta X_{i}-\alpha_{j}\right)-F\left(\beta X_{i}-\alpha_{j+1}\right)$. The parameters of maximum likelihood estimation can be estimated by maximum value of the logarithmic likelihood function. Order Probit regression is:

$$
\begin{aligned}
& \text { Ordered probit }\left(\mathrm{ADP}_{\text {jdo }}\right)=\beta_{0}+\beta_{1} \text { trade }_{\text {jod }}+\beta_{2} \mathrm{gdp}_{\mathrm{d}}+\beta_{3} \mathrm{popu}_{\mathrm{d}}+\beta_{4} \mathrm{dis}_{\text {od }}+\beta_{5} \text { wto } \\
& +\beta_{6} \text { pta }_{o d}+\beta_{7} t a_{o d}+\beta_{8} \text { exch }_{o d}+\beta_{9} \text { crisis }+\chi_{\mathrm{d}}+\mu_{j}+u_{i j}
\end{aligned}
$$

\subsection{Data}

This study including 27 countries and regions with 20 industries between year 1995-2013. The data used in this study includes the export data, SITC two-digits, which comes from the United Nations Conference on Trade and Development (UNCTAD), the anti-dumping data which comes from Bown anti-dumping database. Since the anti-dumping data is counted in HS codes, so we transformed the data into the SITC codes with the transformation between HS and SITC. Besides, the data of GDP per capita and population come from the United Nation Comtrade Database (UNCOMTRADE); the data of exchange rate and tariff come from the World Bank; the data of Free Trade Agreement comes from WTO. Since there are endogeneity problems between anti-dumping and trade, therefore this study takes first-order lag for trade. In addition, this study takes first order 
lag process for GDP per capital and first order difference process for customs duties in dealing with endogeneity problems in the regression.

\section{Results}

\subsection{Basic Results}

Firstly, we analyze the factors which affect anti-dumping investigation by Probit model in columns (1) - (3) of Table1, among which we don't add industry and country characters fixed effects in column (1), add the industry fixed effect in column (2), and add the industry and country characters fixed effects in column (3). The results show that trade, population, GDP per capital, WTO accession, exchange rate and crisis are statistically significant and positive, while distance is statistically significant and negative, free trade agreement and tariff is insignificant, suggesting that the possibility of suffering from anti-dumping investigation increase after increase export to others countries, which is similar with Prusa (2005) Aggarwal (2004) Shen (2007) Wang and Xie (2009), increase in GDP per capita, which is similar with Knetter and Prusa (2003) and Xie (2006), depreciation of RMB against the US dollar, which is similar with Feinberg (1989) Knetter and Prusa (2003), and after China's WTO accession, occurrence of the financial crisis and increase of the population. While the possibility of suffering from anti-dumping investigation decrease after increase the distance within these two countries.

In addition, this study estimates by Order Probit model in columns (4) - (6) in table1, among which we don't add industry and country characters fixed effects in column (1), add the industry fixed effect in column (2), and add the industry and country characters fixed effects in column (3). The results of Order Probit regression show that trade, population, GDP per capital, WTO accession, exchange rate and crisis are statistically significant and positive, while distance is statistically significant and negative, free trade agreement and tariff is insignificant, which support the conclusions in Probit regression.

Table 1. Factors which affect anti-dumping investigation

\begin{tabular}{|c|c|c|c|c|c|c|}
\hline & (1) & (2) & (3) & (4) & (5) & (6) \\
\hline VARIABLES & probit & probit & probit & order probit & order probit & order probit \\
\hline \multirow[t]{2}{*}{ ltrade $_{t-1}$} & $0.085 * * *$ & $0.095^{* *}$ & $0.082^{*}$ & $0.084 * * *$ & $0.079 * *$ & $0.070^{*}$ \\
\hline & {$[0.018]$} & {$[0.041]$} & {$[0.043]$} & [0.017] & [0.039] & {$[0.040]$} \\
\hline \multirow[t]{2}{*}{ lpopu } & $0.179 * * *$ & $0.225 * * *$ & $0.231 * * *$ & $0.179 * * *$ & $0.220 * * *$ & $0.225 * * *$ \\
\hline & {$[0.028]$} & {$[0.038]$} & {$[0.038]$} & {$[0.028]$} & {$[0.036]$} & {$[0.036]$} \\
\hline \multirow[t]{2}{*}{$\operatorname{lavgdp}_{t-1}$} & $0.117 * * *$ & $0.159 * * *$ & $0.123 * * *$ & $0.110 * * *$ & $0.149 * * *$ & $0.112 * * *$ \\
\hline & {$[0.023]$} & {$[0.033]$} & {$[0.041]$} & [0.023] & [0.031] & [0.039] \\
\hline \multirow[t]{2}{*}{ ldis } & $-0.313 * * *$ & $-0.396 * * *$ & $-0.445 * * *$ & $-0.312 * * *$ & $-0.385 * * *$ & $-0.435 * * *$ \\
\hline & [0.047] & {$[0.062]$} & [0.069] & [0.046] & [0.059] & {$[0.066]$} \\
\hline \multirow[t]{2}{*}{ wto } & $0.195 * *$ & $0.243^{* *}$ & $0.282 * *$ & $0.172^{*}$ & $0.210^{* *}$ & $0.244^{* *}$ \\
\hline & [0.091] & [0.111] & [0.112] & {$[0.090]$} & {$[0.106]$} & {$[0.108]$} \\
\hline \multirow[t]{2}{*}{ pta } & 0.125 & 0.121 & 0.16 & 0.099 & 0.085 & 0.121 \\
\hline & {$[0.131]$} & [0.159] & {$[0.164]$} & {$[0.131]$} & {$[0.155]$} & {$[0.159]$} \\
\hline \multirow[t]{2}{*}{$\operatorname{lta}_{\mathrm{t}-1}$} & -0.005 & -0.006 & -0.008 & -0.006 & -0.007 & -0.01 \\
\hline & {$[0.006]$} & [0.007] & [0.007] & {$[0.005]$} & {$[0.006]$} & [0.007] \\
\hline \multirow[t]{2}{*}{ lexchange } & $0.904 * * *$ & $1.120 * * *$ & $1.105^{* * *}$ & $0.879 * * *$ & $1.048 * * *$ & $1.037 * * *$ \\
\hline & {$[0.174]$} & [0.207] & {$[0.210]$} & {$[0.171]$} & {$[0.200]$} & {$[0.202]$} \\
\hline \multirow[t]{2}{*}{ crisis } & $1.000 * * *$ & $1.286 * * *$ & $1.308 * * *$ & $0.991 * * *$ & $1.248 * * *$ & $1.272 * * *$ \\
\hline & {$[0.263]$} & {$[0.310]$} & {$[0.314]$} & {$[0.260]$} & {$[0.300]$} & {$[0.304]$} \\
\hline \multirow[t]{2}{*}{ Constant } & $-10.789 * * *$ & $-13.629 * * *$ & $-12.612 * * *$ & & & \\
\hline & {$[1.566]$} & [1.932] & [2.043] & & & \\
\hline \multirow[t]{2}{*}{ Constant cut 1} & & & & $10.495 * * *$ & $12.637 * * *$ & $11.650 * * *$ \\
\hline & & & & {$[1.542]$} & [1.847] & [1.952] \\
\hline \multirow[t]{2}{*}{ Constant cut 2} & & & & $10.920 * * *$ & $13.155^{* * *}$ & $12.164 * * *$ \\
\hline & & & & {$[1.543]$} & {$[1.848]$} & [1.953] \\
\hline \multirow[t]{2}{*}{ Constant cut 3} & & & & $11.171 * * *$ & $13.436^{* * *}$ & $12.448 * * *$ \\
\hline & & & & {$[1.543]$} & [1.849] & [1.954] \\
\hline Constant cut 4 & & & & $11.328 * * *$ & $13.603 * * *$ & $12.617 * * *$ \\
\hline
\end{tabular}




\begin{tabular}{|c|c|c|c|c|c|c|}
\hline & & & & {$[1.544]$} & {$[1.850]$} & {$[1.954]$} \\
\hline \multirow[t]{2}{*}{ Constant cut5 } & & & & $11.462 * * *$ & $13.740^{* * *}$ & $12.756^{* * *}$ \\
\hline & & & & {$[1.545]$} & {$[1.850]$} & {$[1.955]$} \\
\hline \multirow[t]{2}{*}{ Constant cut6 } & $11.747 * * *$ & $14.022 * * *$ & $13.041^{* * *}$ & $11.747 * * *$ & $14.022 * * *$ & $13.041^{* * *}$ \\
\hline & {$[1.548]$} & {$[1.852]$} & [1.957] & {$[1.548]$} & {$[1.852]$} & {$[1.957]$} \\
\hline Industry fixed effect & NO & YES & YES & NO & YES & YES \\
\hline Country fixed effect & NO & NO & YES & NO & NO & YES \\
\hline Observations & 8,234 & 8,234 & 8,034 & 8,234 & 8,234 & 8,034 \\
\hline
\end{tabular}

Notes: Standard errors reported in brackets: *,**, and *** denote $10 \%, 5 \%$, and $1 \%$ significance levels.

The above results show that the increase of export will increase the chances of suffering from anti-dumping investigation. Therefore, we further study the effect of the trade margin on anti-dumping investigation. First of all, this study tests the effect of extensive margin on suffering from anti-dumping investigation visa Probit and Order Probit model in columns (1) - (3) and (4) - (6) respectively of Table 2, among which we don't add the industry and country characters fixed effects in columns (1) and (4), add the industry fixed effect in columns (2) and (6), and add the industry and country characters fixed effects in columns (3) and (6). Table 2 shows that population, GDP per capital, WTO accession, exchange rate, crisis, distance, free trade agreement and tariff are similar with the results in Table 1 . Besides, if we don't add industry and country characters fixed effects, the extensive margin is statistically significant and positive. However, when add industry and industry-country characters fixed effects, extensive margin is insignificant in Probit model in columns (2) and (3), but statistically significant at 10\% level in Order Probit model in columns (5) and (6). Since it is more strict in adding industry and industry-country characters fixed effects, so the increase of the extensive margin at least don't increase the chances of suffering from anti-dumping investigation based on the columns (2) (3)(5) and(6).

Table 2. The effect of the extensive margin on anti-dumping investigation

\begin{tabular}{|c|c|c|c|c|c|c|}
\hline & $(1)$ & $(2)$ & (3) & $(4)$ & (5) & $(6)$ \\
\hline VARIABLES & probit & probit & probit & order probit & order probit & order probit \\
\hline \multirow[t]{2}{*}{$\operatorname{lexten}_{t-1}$} & $0.295 * * *$ & -0.351 & -0.377 & $0.288 * * *$ & $-0.389^{*}$ & $-0.399 *$ \\
\hline & {$[0.057]$} & {$[0.247]$} & {$[0.249]$} & {$[0.057]$} & {$[0.226]$} & {$[0.228]$} \\
\hline \multirow[t]{2}{*}{ lpopu } & $0.215^{* * *}$ & $0.276^{* * *}$ & $0.277 * * *$ & $0.214 * * *$ & $0.264 * * *$ & $0.265^{* * *}$ \\
\hline & {$[0.027]$} & {$[0.032]$} & {$[0.032]$} & {$[0.027]$} & {$[0.031]$} & {$[0.031]$} \\
\hline \multirow[t]{2}{*}{ lavgdp $p_{t-1}$} & $0.161 * * *$ & $0.217 * * *$ & $0.165 * * *$ & $0.154 * * *$ & $0.201 * * *$ & $0.149 * * *$ \\
\hline & {$[0.021]$} & {$[0.026]$} & {$[0.037]$} & {$[0.021]$} & {$[0.025]$} & {$[0.036]$} \\
\hline \multirow[t]{2}{*}{ ldis } & $-0.367 * * *$ & $-0.479 * * *$ & $-0.526 * * *$ & $-0.365 * * *$ & $-0.459 * * *$ & $-0.507 * * *$ \\
\hline & {$[0.046]$} & {$[0.056]$} & {$[0.061]$} & {$[0.045]$} & {$[0.053]$} & {$[0.058]$} \\
\hline \multirow[t]{2}{*}{ wto } & $0.241 * * *$ & $0.326 * * *$ & $0.361 * * *$ & $0.218^{* *}$ & $0.283 * * *$ & $0.314 * * *$ \\
\hline & {$[0.090]$} & {$[0.107]$} & [0.109] & {$[0.089]$} & {$[0.103]$} & {$[0.105]$} \\
\hline \multirow[t]{2}{*}{ pta } & 0.154 & 0.195 & 0.246 & 0.128 & 0.152 & 0.198 \\
\hline & {$[0.131]$} & [0.159] & {$[0.162]$} & {$[0.131]$} & {$[0.154]$} & {$[0.158]$} \\
\hline \multirow[t]{2}{*}{$1 \mathrm{ta}_{\mathrm{t}-1}$} & -0.003 & -0.003 & -0.006 & -0.004 & -0.005 & -0.008 \\
\hline & {$[0.005]$} & {$[0.006]$} & {$[0.007]$} & {$[0.005]$} & {$[0.006]$} & {$[0.006]$} \\
\hline \multirow[t]{2}{*}{ lexchange } & $0.829 * * *$ & $1.048 * * *$ & $1.042 * * *$ & $0.804 * * *$ & $0.990 * * *$ & $0.986^{* * *}$ \\
\hline & {$[0.174]$} & {$[0.205]$} & {$[0.207]$} & {$[0.171]$} & {$[0.198]$} & {$[0.200]$} \\
\hline \multirow[t]{2}{*}{ crisis } & $0.965 * * *$ & $1.274 * * *$ & $1.301 * * *$ & $0.956^{* * *}$ & $1.241 * * *$ & $1.270 * * *$ \\
\hline & {$[0.264]$} & {$[0.312]$} & {$[0.316]$} & {$[0.261]$} & {$[0.302]$} & {$[0.306]$} \\
\hline \multirow[t]{2}{*}{ Constant } & $-10.067 * * *$ & $-12.426^{* * *}$ & $-11.338 * * *$ & & & \\
\hline & {$[1.553]$} & [1.877] & {$[1.965]$} & & & \\
\hline \multirow[t]{2}{*}{ Constant cut 1} & & & & $9.781 * * *$ & $11.607 * * *$ & $10.549 * * *$ \\
\hline & & & & [1.529] & [1.797] & {$[1.881]$} \\
\hline Constant cut 2 & & & & $10.207 * * *$ & $12.125^{* * *}$ & $11.064 * * *$ \\
\hline
\end{tabular}




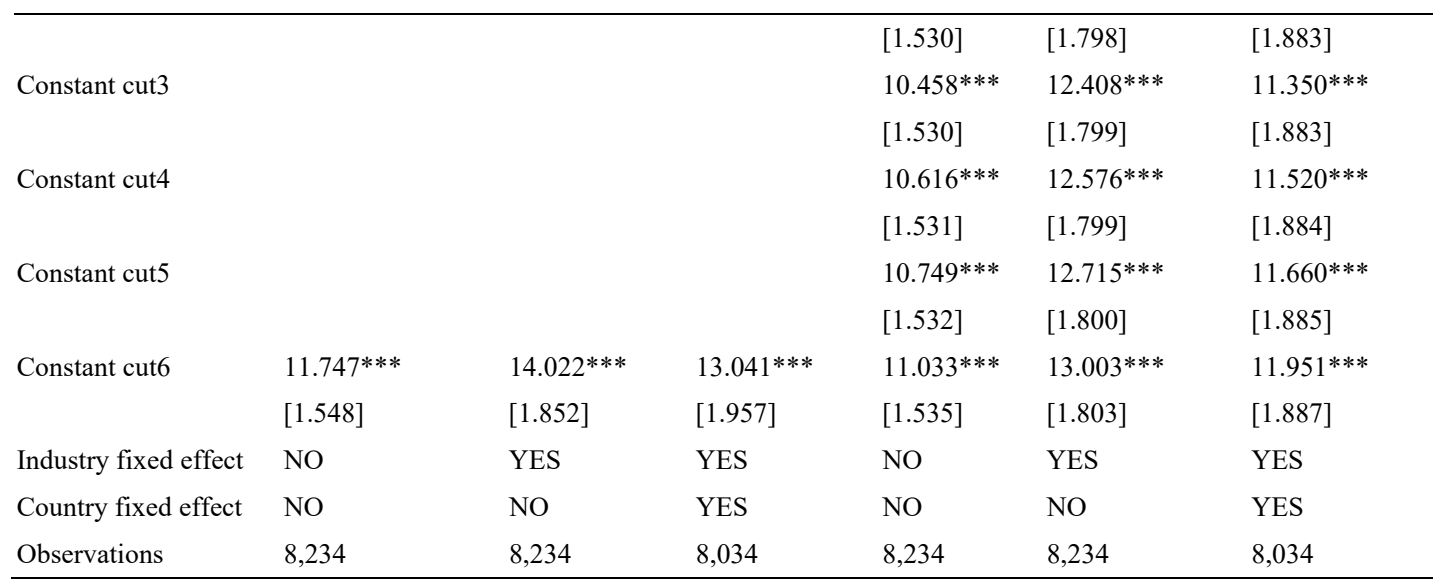

Notes: Standard errors reported in brackets: ${ }^{*}, *$, and ${ }^{* * *}$ denote $10 \%, 5 \%$, and $1 \%$ significance levels.

Table 3 is the effect of intensive margin on suffering from anti-dumping investigation by Probit and Order Probit model in columns (1) - (3) and (4) - (6) respectively, among which we don't add the industry and country characters fixed effects in columns (1) and (4), add industry fixed effect in columns (2) and (6), and add the industry and country characters fixed effects in columns (3) and (6). The regressions of Table 3 infer that population, GDP per capital, WTO accession, exchange rate, crisis, distance, free trade agreement and tariff are similar with the results in Table 1. Besides, the intensive margin has a statistically significant and positive effect on suffering from anti-dumping investigation, which indicates that the increase of intensive margin will increase the chances of suffering from anti-dumping investigation. The above results infer that the effect of trade on suffering from anti-dumping investigation originally comes from the intensive margin. The extensive margin at least doesn't increase the chances of suffering from anti-dumping investigation.

Table 3. The effect of intensive margin on anti-dumping investigation

\begin{tabular}{|c|c|c|c|c|c|c|}
\hline & (1) & (2) & (3) & (4) & (5) & (6) \\
\hline VARIABLES & probit & probit & probit & order probit & order probit & order probit \\
\hline \multirow[t]{2}{*}{$\operatorname{linten}_{t-1}$} & $0.089 * * *$ & $0.110^{* *}$ & $0.097 * *$ & $0.088 * * *$ & $0.095^{* *}$ & $0.086^{* *}$ \\
\hline & {$[0.021]$} & {$[0.043]$} & {$[0.045]$} & {$[0.021]$} & {$[0.041]$} & {$[0.042]$} \\
\hline \multirow[t]{2}{*}{ lpopu } & $0.178 * * *$ & $0.219 * * *$ & $0.225^{* * *}$ & $0.177 * * *$ & $0.214 * * *$ & $0.218 * * *$ \\
\hline & {$[0.028]$} & {$[0.038]$} & {$[0.038]$} & {$[0.028]$} & {$[0.036]$} & {$[0.036]$} \\
\hline \multirow[t]{2}{*}{$\operatorname{lavgdp}_{t-1}$} & $0.115^{* * *}$ & $0.153^{* * *}$ & $0.119 * * *$ & $0.108 * * *$ & $0.142 * * *$ & $0.107 * * *$ \\
\hline & {$[0.024]$} & {$[0.033]$} & {$[0.040]$} & {$[0.024]$} & {$[0.031]$} & [0.039] \\
\hline \multirow[t]{2}{*}{ ldis } & $-0.310 * * *$ & $-0.388 * * *$ & $-0.435 * * *$ & $-0.309 * * *$ & $-0.376 * * *$ & $-0.424 * * *$ \\
\hline & {$[0.048]$} & {$[0.062]$} & {$[0.069]$} & {$[0.047]$} & {$[0.059]$} & {$[0.066]$} \\
\hline \multirow[t]{2}{*}{ wto } & $0.195^{* *}$ & $0.236^{* *}$ & $0.275^{* *}$ & $0.172 *$ & $0.202^{*}$ & $0.236^{* *}$ \\
\hline & {$[0.091]$} & {$[0.110]$} & {$[0.112]$} & {$[0.090]$} & {$[0.106]$} & {$[0.108]$} \\
\hline \multirow[t]{2}{*}{ pta } & 0.127 & 0.117 & 0.154 & 0.101 & 0.08 & 0.113 \\
\hline & {$[0.131]$} & {$[0.159]$} & {$[0.164]$} & {$[0.130]$} & {$[0.154]$} & {$[0.159]$} \\
\hline \multirow[t]{2}{*}{$1 t a_{t-1}$} & -0.005 & -0.006 & -0.008 & -0.006 & -0.008 & -0.01 \\
\hline & {$[0.006]$} & {$[0.007]$} & {$[0.007]$} & {$[0.005]$} & {$[0.006]$} & {$[0.007]$} \\
\hline \multirow[t]{2}{*}{ lexchange } & $0.910 * * *$ & $1.135^{* * *}$ & $1.120 * * *$ & $0.885^{* * *}$ & $1.064 * * *$ & $1.053 * * *$ \\
\hline & {$[0.174]$} & {$[0.208]$} & {$[0.210]$} & {$[0.171]$} & {$[0.200]$} & {$[0.202]$} \\
\hline \multirow[t]{2}{*}{ crisis } & $1.004 * * *$ & $1.292 * * *$ & $1.314 * * *$ & $0.996 * * *$ & $1.255^{* * *}$ & $1.278 * * *$ \\
\hline & {$[0.263]$} & {$[0.310]$} & {$[0.314]$} & {$[0.260]$} & {$[0.300]$} & {$[0.304]$} \\
\hline \multirow[t]{2}{*}{ Constant } & $-10.733 * * *$ & $-13.735 * * *$ & $-12.756 * * *$ & & & \\
\hline & {$[1.566]$} & [1.931] & {$[2.041]$} & & & \\
\hline \multirow[t]{2}{*}{ Constant cut 1} & & & & $10.447 * * *$ & $12.762 * * *$ & $11.811^{* * *}$ \\
\hline & & & & {$[1.542]$} & [1.846] & {$[1.952]$} \\
\hline
\end{tabular}




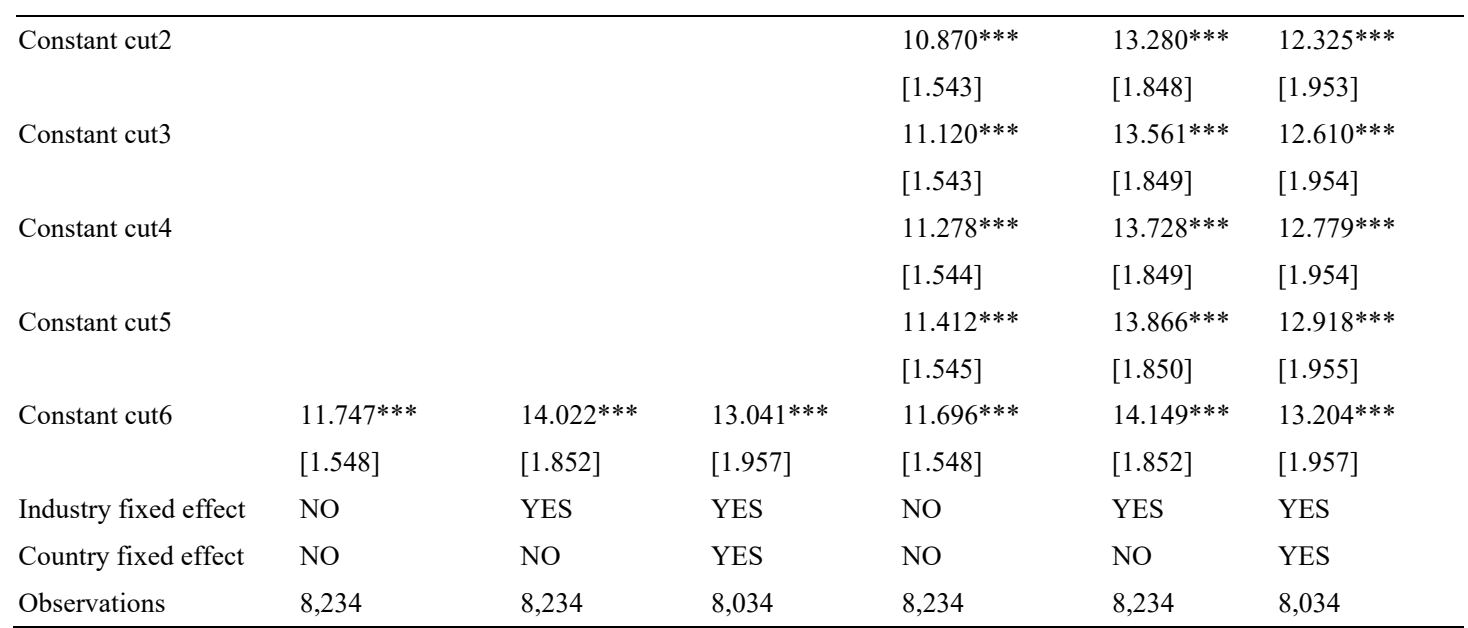

Notes: Standard errors reported in brackets: *,*, and $* * *$ denote $10 \%, 5 \%$, and $1 \%$ significance levels.

We further analyze the marginal effect of Probit model in Table 4, among which we don't add industry and country characters fixed effects in columns (1), (4) and (7), add the industry fixed effect in columns (2), (5) and (8), and add industry and country characters fixed effects in columns (3), (6) and (9). Table 4 infers that with the export increased by $1 \%$, the chances of suffering from anti-dumping investigation increase 0.004 ; with the intensive margin increased by $1 \%$, the chances of suffering from anti-dumping investigation increase 0.003 ; with destination country's population increased by $1 \%$, the chances of suffering from anti-dumping investigation increase 0.009 ; with the GDP per capital increased by $1 \%$, the chances of suffering from anti-dumping investigation increase 0.005 ; with the distance increased by $1 \%$, the chances of suffering from anti-dumping investigation reduce 0.017; with WTO accession, the chances of suffering from anti-dumping investigation increased 0.011 ; with the appreciation of RMB $1 \%$, the chances of suffering from anti-dumping investigation increase 0.039; with the crisis, the chances of suffering from anti-dumping investigation increase 0.047 . The above results infer that the depression of the RMB, the occurrence of the crisis and China's WTO accession are the main factors affecting the suffering of anti-dumping investigation.

Table 4. Marginal effect (dy/dx) of Probit model

\begin{tabular}{llllllllll}
\hline & $(1)$ & $(2)$ & $(3)$ & $(4)$ & $(5)$ & $(6)$ & $(7)$ & $(8)$ & $(9)$ \\
\hline trade $_{\mathrm{t}-1}$ & $0.004^{* * *}$ & $0.004^{* *}$ & $0.003^{*}$ & & & & & & \\
lexten $_{\mathrm{t}-1}$ & & & & $0.013^{* * *}$ & -0.012 & -0.013 & & & \\
linten $\mathrm{t}_{-1}$ & & & & & & & $0.004^{* * *}$ & $0.003^{* *}$ & $0.003^{* *}$ \\
lpopu & $0.008^{* * *}$ & $0.008^{* * *}$ & $0.008^{* * *}$ & $0.010^{* * *}$ & $0.010^{* * *}$ & $0.010^{* * *}$ & $0.008^{* * *}$ & $0.008^{* * *}$ & $0.008^{* * *}$ \\
lavgdp $\mathrm{t}-1$ & $0.005^{* * *}$ & $0.005^{* * *}$ & $0.004^{* * *}$ & $0.007^{* * *}$ & $0.008^{* * *}$ & $0.006^{* * *}$ & $0.005^{* * *}$ & $0.006^{* * *}$ & $0.004^{* * *}$ \\
ldis & $-0.014^{* * *}$ & $-0.014^{* * *}$ & $-0.015^{* * *}$ & $-0.016^{* * *}$ & $-0.017^{* * *}$ & $-0.019^{* * *}$ & $-0.014^{* * *}$ & $-0.014^{* * *}$ & $-0.016^{* * *}$ \\
wto & $0.009^{* *}$ & $0.008^{* *}$ & $0.010^{* *}$ & $0.011^{* * *}$ & $0.012^{* * *}$ & $0.013^{* * *}$ & $0.009^{* *}$ & $0.009^{* *}$ & $0.010^{* *}$ \\
pta & 0.006 & 0.004 & 0.005 & 0.007 & 0.007 & 0.009 & 0.006 & 0.004 & 0.006 \\
ta $\mathrm{t}_{\mathrm{t}-1}$ & 0.000 & 0.000 & 0.000 & 0.000 & 0.000 & $0.000^{*}$ & 0.000 & 0.000 & 0.000 \\
exchange & $0.040^{* * *}$ & $0.040^{* * *}$ & $0.040^{* * *}$ & $0.037^{* * *}$ & $0.037^{* * *}$ & $0.037^{* * *}$ & $0.040^{* * *}$ & $0.040^{* * *}$ & $0.039^{* * *}$ \\
crisis & $0.045^{* * *}$ & $0.046^{* * *}$ & $0.047^{* * *}$ & $0.043^{* * *}$ & $0.045^{* * *}$ & $0.046^{* * * *}$ & $0.044^{* * *}$ & $0.045^{* * *}$ & $0.047^{* * *}$ \\
\hline
\end{tabular}

Notes: Standard errors reported in brackets: ${ }^{* *}$, , and $* * *$ denote $10 \%, 5 \%$, and $1 \%$ significance levels.

\subsection{Robustness Test}

If the data contains a large number of 0 values, we will consider to estimate in zero expansion Poisson regression. 
The data in this study shows that the number of 0 values in dependent variable is 8986 , accounting for $97.89 \%$ of total sample in Table5, so zero expansion Poisson regression is used to test the robustness of the results. In addition, if data $Y_{i}$ compress to one point, the probability distribution of $Y_{i}$ becomes a mixture distribution of discrete point and continuous distribution, then Tobit model will be better. Therefore, this study uses zero expansion Poisson regression and the Tobit regression to test the robustness.

Table 5. The distribution of anti-dumping investigation in data

\begin{tabular}{llll}
\hline number & Freq. & Percent & Cum. \\
\hline 0 & 8,986 & 97.89 & 97.89 \\
1 & 121 & 1.32 & 99.2 \\
2 & 37 & 0.4 & 99.61 \\
3 & 12 & 0.13 & 99.74 \\
4 & 7 & 0.08 & 99.81 \\
5 & 6 & 0.07 & 99.88 \\
6 & 1 & 0.01 & 99.89 \\
7 & 2 & 0.02 & 99.91 \\
8 & 1 & 0.01 & 99.92 \\
11 & 6 & 0.07 & 99.99 \\
25 & 1 & 0.01 & 100 \\
Total & 9,180 & 100 & Total \\
\hline
\end{tabular}

Table 6. Zero inflation Poisson regression

\begin{tabular}{|c|c|c|c|c|c|c|}
\hline & (1) & (2) & (3) & (4) & (5) & (6) \\
\hline VARIABLES & ADP3 & ADP3 & ADP3 & ADP2 & ADP2 & ADP2 \\
\hline \multirow[t]{2}{*}{ ltrade $_{t-1}$} & $0.145^{* *}$ & & & 0.055 & & \\
\hline & {$[0.065]$} & & & {$[0.075]$} & & \\
\hline \multirow[t]{2}{*}{ lexten $_{t-1}$} & & $0.451^{* * *}$ & & & $-1.534 * * *$ & \\
\hline & & {$[0.128]$} & & & {$[0.383]$} & \\
\hline \multirow[t]{2}{*}{ linten $_{t-1}$} & & & $0.183^{* * *}$ & & & 0.118 \\
\hline & & & {$[0.069]$} & & & {$[0.081]$} \\
\hline \multirow[t]{2}{*}{ lpopu } & $0.401 * * *$ & $0.492 * * *$ & $0.387 * * *$ & $0.363^{* * *}$ & $0.420 * * *$ & $0.334 * * *$ \\
\hline & {$[0.065]$} & {$[0.060]$} & {$[0.065]$} & {$[0.081]$} & {$[0.070]$} & {$[0.083]$} \\
\hline \multirow[t]{2}{*}{ lavgdp $p_{t-1}$} & 0.037 & $0.132^{* * *}$ & 0.028 & 0.010 & 0.069 & -0.009 \\
\hline & {$[0.063]$} & {$[0.047]$} & {$[0.063]$} & {$[0.067]$} & {$[0.062]$} & {$[0.067]$} \\
\hline \multirow[t]{2}{*}{ ldis } & $-0.736^{* * *}$ & $-0.637^{* * *}$ & $-0.718^{* * *}$ & $-0.650 * * *$ & $-0.742 * * *$ & $-0.617^{* * *}$ \\
\hline & {$[0.102]$} & {$[0.087]$} & {$[0.102]$} & {$[0.108]$} & {$[0.099]$} & {$[0.110]$} \\
\hline \multirow[t]{2}{*}{ wto } & 0.289 & 0.099 & 0.267 & 0.239 & $0.366^{* *}$ & 0.192 \\
\hline & {$[0.177]$} & {$[0.171]$} & {$[0.177]$} & {$[0.181]$} & {$[0.173]$} & {$[0.182]$} \\
\hline \multirow[t]{2}{*}{ pta } & -0.066 & -0.112 & -0.070 & -0.010 & 0.143 & -0.022 \\
\hline & {$[0.308]$} & {$[0.307]$} & {$[0.308]$} & {$[0.328]$} & {$[0.328]$} & {$[0.330]$} \\
\hline \multirow[t]{2}{*}{$\mathrm{ta}_{\mathrm{t}-1}$} & $-0.028^{* *}$ & $-0.023 * *$ & $-0.028 * *$ & $-0.033 * * *$ & $-0.025 * *$ & $-0.035^{* * *}$ \\
\hline & {$[0.011]$} & {$[0.011]$} & {$[0.011]$} & {$[0.012]$} & {$[0.011]$} & {$[0.012]$} \\
\hline exchange & $2.403 * * *$ & $1.758 * * *$ & $2.415^{* * *}$ & $2.596 * * *$ & $2.652 * * *$ & $2.559 * * *$ \\
\hline
\end{tabular}




\begin{tabular}{|c|c|c|c|c|c|c|}
\hline & {$[0.356]$} & {$[0.351]$} & {$[0.355]$} & {$[0.451]$} & {$[0.448]$} & {$[0.456]$} \\
\hline \multirow{2}{*}{ crisis } & $3.423 * * *$ & $2.563 * * *$ & $3.397 * * *$ & $3.697 * * *$ & $3.889 * * *$ & $3.561 * * *$ \\
\hline & {$[0.567]$} & {$[0.551]$} & {$[0.566]$} & {$[0.750]$} & {$[0.721]$} & {$[0.763]$} \\
\hline \multirow[t]{2}{*}{ Constant } & $-20.997 * * *$ & $-16.791 * * *$ & $-21.185 * * *$ & $-18.760 * * *$ & $-18.387 * * *$ & $-18.533 * * *$ \\
\hline & {$[3.266]$} & [3.169] & {$[3.260]$} & {$[4.258]$} & [4.229] & {$[4.292]$} \\
\hline Industry fixed effect & YES & YES & YES & YES & YES & YES \\
\hline Country fixed effect & YES & YES & YES & YES & YES & YES \\
\hline Observations & 8,034 & 8,234 & 8,034 & 8,034 & 8,034 & 8,034 \\
\hline
\end{tabular}

Notes: Standard errors reported in brackets: $*, * *$, and $* * *$ denote $10 \%, 5 \%$, and $1 \%$ significance levels.

Firstly, we estimate in zero expansion Poisson model for robustness test in Table 6, among which we use ADP3 in columns (1) - (3), and ADP2 in columns (4) - (6) respectively. By added the industry and country characters fixed effects, the results show that when we used ADP3, excepted WTO accession and GDP per capital, which are statistically insignificant, tariff and extensive margin, which are statistically significant and negative, the others variables are consistent with the previous results. When we use ADP2, excepted GDP per capital and trade which are insignificant, the others variables are consistent with the previous results.

Table 7. The Tobit regression

\begin{tabular}{|c|c|c|c|c|c|c|}
\hline & (1) & (2) & (3) & (4) & (5) & (6) \\
\hline VARIABLES & ADP3 & ADP3 & ADP3 & ADP2 & ADP2 & ADP2 \\
\hline \multirow[t]{2}{*}{ ltrade $_{t-1}$} & $0.261^{*}$ & & & $0.384 *$ & & \\
\hline & {$[0.150]$} & & & {$[0.209]$} & & \\
\hline \multirow[t]{2}{*}{$\operatorname{lexten}_{t-1}$} & & $-1.453 *$ & & & $-2.079^{*}$ & \\
\hline & & {$[0.844]$} & & & {$[1.160]$} & \\
\hline \multirow[t]{2}{*}{ linten $_{t-1}$} & & & $0.320^{* *}$ & & & $0.473 * *$ \\
\hline & & & {$[0.156]$} & & & [0.219] \\
\hline \multirow[t]{2}{*}{ lpopu } & $0.831 * * *$ & $0.977 * * *$ & $0.806 * * *$ & $1.129 * * *$ & $1.344 * * *$ & $1.090 * * *$ \\
\hline & {$[0.142]$} & {$[0.127]$} & {$[0.142]$} & [0.199] & {$[0.177]$} & {$[0.199]$} \\
\hline \multirow[t]{2}{*}{ lavgdp $\mathrm{p}_{\mathrm{t}-1}$} & $0.414 * * *$ & $0.551 * * *$ & $0.394 * * *$ & $0.533 * * *$ & $0.737 * * *$ & $0.503^{* *}$ \\
\hline & {$[0.147]$} & {$[0.135]$} & {$[0.146]$} & {$[0.206]$} & {$[0.190]$} & {$[0.206]$} \\
\hline \multirow[t]{2}{*}{ ldis } & $-1.604 * * *$ & $-1.865 * * *$ & $-1.564 * * *$ & $-2.132 * * *$ & $-2.517 * * *$ & $-2.071 * * *$ \\
\hline & {$[0.260]$} & {$[0.240]$} & {$[0.259]$} & {$[0.363]$} & {$[0.336]$} & {$[0.361]$} \\
\hline \multirow[t]{2}{*}{ wto } & $0.900^{* *}$ & $1.158^{* * *}$ & $0.868^{* *}$ & $1.137 * *$ & $1.520 * * *$ & $1.088^{*}$ \\
\hline & {$[0.402]$} & [0.391] & {$[0.401]$} & {$[0.564]$} & {$[0.549]$} & {$[0.563]$} \\
\hline \multirow[t]{2}{*}{ pta } & 0.445 & 0.731 & 0.418 & 0.544 & 0.964 & 0.504 \\
\hline & [0.589] & {$[0.583]$} & {$[0.588]$} & {$[0.829]$} & {$[0.822]$} & {$[0.828]$} \\
\hline \multirow[t]{2}{*}{$\mathrm{tat}_{\mathrm{t}-1}$} & -0.036 & -0.028 & -0.037 & -0.051 & -0.039 & -0.052 \\
\hline & {$[0.024]$} & {$[0.024]$} & {$[0.025]$} & {$[0.034]$} & {$[0.034]$} & {$[0.035]$} \\
\hline \multirow[t]{2}{*}{ exchange } & $3.884 * * *$ & $3.676^{* * *}$ & $3.937 * * *$ & $5.449 * * *$ & $5.147 * * *$ & $5.527 * * *$ \\
\hline & {$[0.784]$} & {$[0.770]$} & {$[0.786]$} & {$[1.102]$} & {$[1.084]$} & {$[1.104]$} \\
\hline
\end{tabular}




\begin{tabular}{|c|c|c|c|c|c|c|}
\hline \multirow[t]{2}{*}{ crisis } & $4.770 * * *$ & $4.742 * * *$ & $4.787 * * *$ & $6.786 * * *$ & $6.754 * * *$ & $6.811 * * *$ \\
\hline & [1.162] & [1.164] & [1.161] & {$[1.637]$} & {$[1.641]$} & {$[1.635]$} \\
\hline \multirow[t]{2}{*}{ Constant } & $-43.549 * * *$ & $-39.306 * * *$ & $-44.097 * * *$ & $-61.002 * * *$ & $-54.909 * * *$ & $-61.822 * * *$ \\
\hline & {$[7.750]$} & [7.382] & {$[7.752]$} & [10.859] & {$[10.360]$} & [10.859] \\
\hline Industry fixed effect & YES & YES & YES & YES & YES & YES \\
\hline Country fixed effect & YES & YES & YES & YES & YES & YES \\
\hline Observations & 8,034 & 8,034 & 8,034 & 8,034 & 8,034 & 8,034 \\
\hline
\end{tabular}

Notes: Standard errors reported in brackets: *,**, and *** denote $10 \%, 5 \%$, and $1 \%$ significance levels.

Follows, this study estimates in Tobit model in table 7, among which we use ADP3 in columns (1) - (3), ADP2 in columns (4) - (6) respectively. With added industry and country characters fixed effects, the results show that the variables in the regression are consistent with the previous results. Besides, the results infer that the increase of extensive margin will decline the chances of suffering from anti-dumping investigation. The above robustness tests support the previous conclusions.

\section{Conclusions}

As Trump was elected as the new president of the United States, the trend of trade protection booms again. This study using the data of 27 countries and regions with 20 industries during 1997-2013 via Probit and Order Probit model tests the factors which affect the suffering of anti-dumping investigation. We find that export, GDP per capita, population, distance, exchange rate, WTO accession and financial crisis have a statistically significant effect on anti-dumping investigation, among which export, GDP per capita, population, exchange rate, WTO accession and financial crisis increase the chances of suffering from anti-dumping investigation; the distance decrease the chances of suffering from anti-dumping investigation. Besides, in order to test the effect of export on anti-dumping investigation, we divide the export into extensive margin and intensive margin. We find that the increase of extensive margin at least doesn't increase the chances of suffering from anti-dumping investigation, while the increase of intensive margin tends to increase the chances of suffering from anti-dumping investigation, which infers that the effect of trade on anti-dumping investigations mainly comes from the intensive margin.

\section{References}

Aggarwal, A. (2004). Macro economic determinants of antidumping: A comparative analysis of developed and developing countries. World Development, 32(6), 1043-1057.

Baldwin, R. E. (1985). The political economy of U.S. import policy. MIT Press.

Dutt, P., Mihov, I., \& Van Zandt, T. (2013). The Effect of WTO on the Extensive and the Intensive Margins of Trade. Journal of international Economics, 91(2), 204-219.

Feinberg, R. M., \& Hirsch, B. T. (1989). Industry rent seeking and the filing of 'unfair trade' complaints. International Journal of Industrial Organization, 7(3), 325-340.

Feinberg, R. M., \& Reynolds, K. M. (2007). Tariff liberalization and increased administrative protection: is there a quid pro quo?. World Economy, 30(6), 948-961.

Hummels, D., \& Klenow, P. J. (2005). The variety and quality of a nation's exports. American Economic Review, 95(3), 704-723.

Irwin, D. A. (2005). The rise of us anti-dumping activity in historical perspective. World Economy, 28(5), 651-668.

Knetter, M. M., \& Prusa, T. J. (2003). Macroeconomic factors and antidumping filings: evidence from four countries. Journal of International Economics, 61(1), 1-17.

Mah, Jai S. (2000). Antidumping decisions and macroeconomic variables in the USA. Applied Economics, 32(13), 1701-1709.

Prusa, T. J. (2005). Anti-dumping: a growing problem in international trade. World Economy, 28(5), 683-700.

Shen, G. B. (2007). The macro determinants and effects of American antidumping to China. The Journal of World Economy, (11), 11-23. 
Wang, X. S., \& Xie, S. X. (2009). Why China has encountered antidumping-empirical analysis based on countryindustry lever data. Management World(monthly), (12), 27-38.

Xie, J. G. (2006). Economic impact, divergence in politics, and clashes in systems: a case study of US antidumping filing against China. Management World(monthly), (12), 8-17.

Zhang, W. F., \& Qi, W. (2005). Theoretical study on index of export products' antidumping early warning system. Journal of University of International Business and Economics: International Business Edition, (4), 25-30.

\section{Copyrights}

Copyright for this article is retained by the author(s), with first publication rights granted to the journal.

This is an open-access article distributed under the terms and conditions of the Creative Commons Attribution license (http://creativecommons.org/licenses/by/4.0/). 